Hochstrasser, K. \& Werle, E. (1967). Hoppe-Seyl. Z. 348, 177.

Holman, G., Lowe, J. S., Morley, J. S. \& Smithers, M. J. (1968). Biochem. biophys. Res. Commun. 33, 140.

Mares-Guia, M. \& Diniz, C. R. (1967). Arch. Biochem. Biophys. 121, 750.

Moriya, H., Kato, A. \& Fukushima, H. (1969). Biochem. Pharmacol. 18, 549.
Nagasawa, S., Takahashi, H., Koida, M., Suzuki, T. \& Schoenmakers, J. G. G. (1968). Biochem. biophys. Res. Commun., 32, 644.

Paskhina, T. S., Zhukova, V. P., Egorova, T. P., Narticova, V. F., Karpova, A. V. \& Guseva, M. V. (1968). Biokhimiya, 83, 745.

Sach, E. \& Thely, M. (1968). C. R. Acad. Sci., Paris, 266, 1200.

\title{
COMMUNICATIONS
}

\section{Purification and Characterization of Bovine Enteroviruses}

By M. D. Johnston, S. J. Martin and J. B. Clements. (Department of Biochemistry, Queen's University, Belfast)

Bovine enteroviruses are widely distributed in the cattle population of Ireland. Recent reports (McFerran, Nelson, McCracken \& Ross, 1969) indicate their economic importance in relation to enteritis.

Serologically distinct bovine enteroviruses have been shown to grow readily in baby-hamster kidney (BHK) cells. This system has been used to grow virus in sufficient quantity for the investigation of their nucleic acid and protein components.

Overnight incubation of virus with monolayers of BHK cells disrupts the cell sheet, releasing over $99 \%$ of the virus formed into the medium. The bulk of the cell debris is removed by centrifugation at 2000 rev./min. Remaining cellular contamination is then removed by differential centrifugation, gel filtration through Sepharose $2 \mathrm{~B}$ and sedimentation in $15-40 \%$ sucrose gradients. The purity of the virus has been demonstrated by double-labelling experiments and detergent treatment. This purification scheme is readily adaptable to large-scale zonal-centrifugation procedures.

The nucleic acid of the viruses has been identified as RNA by labelling with $\left[{ }^{3} \mathrm{H}\right]$ uridine. On sucrose gradients viral RNA sediments at $35 \mathrm{~s}$ relative to $28 \mathrm{~s}$ ribosomal RNA. The base compositions of RNA from several serologically distinct bovine enteroviruses are similar. The viruses have a sedimentation value of $165 \mathrm{~s}$ relative to $80 \mathrm{~s}$ ribosomes extracted from BHK cells. Electronmicroscope studies have shown the virus particles to be spherical with a diameter of $27 \mathrm{~nm}$. Their density is $1.34 \mathrm{~g} . / \mathrm{ml}$. as determined by density of the isopyenic centrifugation in $\mathrm{CsCl}$ gradients run in angle heads (Flamm, Bond \& Burr, 1966).

Work is now in progress to study the capsid proteins of a number of bovine enteroviruses.
We are grateful to the Agricultural Research Council for a grant to support this work.

Flamm, W. G., Bond, H. E. \& Burr, H. E. (1966). Biochim. biophys. Acta, 129, 310.

McFerran, J. B., Nelson, R., McCracken, J. M. \& Ross, J. G. (1969). Nature, Lond., 221, 194.

\section{The Reaction Catalysed by a Partially Purified Nucleoside Triphosphate-Dependent Deoxy- ribonucleic Acid-Breakdown System from Mycobacterium smegmatis}

By F. G. Winder and M. LAvin. (Department of Biochemistry, Trinity College, Dublin, Irish Republic)

Streptomycin-treated extracts of Mycobacterium smegmatis that had been grown for $72 \mathrm{hr}$. in ironlimited medium were prepared as described by Winder \& Coughlan (1969). Protamine sulphate $(0 \cdot 1 \%)$ was added, and the precipitate was dissolved in $0.1 \mathrm{M}$-phosphate buffer, $\mathrm{pH} 7 \cdot 5$, containing $1 \mathrm{mM}$ dithiothreitol, concentrated on a Diaflo UM-10 ultrafilter, transferred to a column of Sephadex G-200 and eluted with 0.1 M-phosphate buffer, pH 8.0, containing $1 \mathrm{~mm}$-dithiothreitol. The enzyme was eluted immediately after the void volume, with a 15-20-fold increase in specific activity over the crude extract. Attempts at further purification were unsuccessful owing to low stability.

Incubation mixtures contained usually $0.2 \mathrm{ml}$. of enzyme, $0.4 \mathrm{ml}$. of the latter buffer, $1 \mathrm{mg}$. of the sodium salt of DNA, $2 \mu$ moles of ATP and $20 \mu$ moles of $\mathrm{MgCl}_{2}$ in a total volume of $1 \mathrm{ml}$., or was appropriately scaled up. It was incubated at $37^{\circ}$, usually for $30 \mathrm{~min}$. Assays were as described by Winder \& Coughlan (1969).

The enzyme strongly preferred native to heatdenatured DNA. However, it could degrade more than half of the DNA, probably as the result of a slow attack on single-stranded DNA. The kinetics of loss of viscosity of the DNA and of appearance of acid-soluble deoxyribose were similar, and extraction of DNA remaining after a period of 